\title{
Implementation of Financial Inclusion Strategy in Nigeria ${ }^{\#}$
}

Stephen Aro-Gordon*

Adjunct Faculty, SDMIMD, Mysuru - 570011, Karnataka, India

Department of Accounting \& Finance, Baze University, Abuja - 900108, FCT, Nigeria

\begin{abstract}
While global effort towards effective financial inclusion strategy has heightened over the past decade because of its positive correlation with improved income, employment generation, poverty reduction, and a stable financial system, research to date has not given adequate attention to the efficacy of national financial inclusion policy implementation in Nigeria, Africa's most populous nation. This paper applies the theory of change to critically evaluate how Nigeria's National Financial Inclusion Strategy launched in 2012 is working towards achieving its set goal of reducing financial exclusion from 46.3 percent in 2010 to 20.0 percent by 2020 . Annual data spanning 2008 to 2016 sourced from the World Bank's Global Financial Inclusion database, the Central Bank of Nigeria, and Enhancing Financial Innovation and Access (EFInA) biennial surveys, were analyzed using descriptive statistics, tables and graphs to show the trend of key variables and regional differences. Progress made on nine key performance indicators (KPIs) of financial inclusion were investigated nationally and geopolitically. While Nigeria's financial exclusion rate has reduced from 52.5 percent in 2008 to 41.6 percent in 2016, more than half (55.4\%) of the female adult population still remained excluded. The South-West geopolitical zone has surpassed the 20 percent exclusion rate target, but the remaining zones, particularly in the Northern part of the country, remain largely financially excluded. Out of the nine major KPIs, expansion of banks' branches and penetration of the agency banking system are the only two indicators that have recorded high level achievement towards meeting the 2020 targets. Evidently, concerted implementation is needed to achieve financial inclusion in Nigeria. To this end, the paper recommends a four-pillar implementation framework anchored on enhanced businessfriendly environment, financial innovation, mobile capacity, and robust financial education.
\end{abstract}

Keywords: Financial education, Financial inclusion products, Financial sector operators, Microfinance, Strategic management, Theory of change

\section{Introduction}

The growing importance of financial inclusion, especially in developing economies, is perhaps underscored by the award of the 2006 Nobel Peace Prize to Grameen Bank and Professor Mohammad Yunus who pioneered the concept of microfinance in Bangladesh. Yet, while considerable improvement has been recorded in expanding financial inclusion in the past decade, over half of the world's population still does not have access to basic financial services - payments / remittances, savings, credit, insurance and pension. About 60 percent of people in poor countries do not have access to these basic financial services, thereby constraining global capacity for inclusive growth, where growth is broad-based and ensures the widest possible benefits to a nation's citizentry (Frisby, 2014, Demirguc-Kunt, et al. 2015, Ozughalu \& Ogwumike, 2015). Inclusiveness is pivotal to any sustainable growth strategy since in an inclusive economy, economic activities and structures of production would involve overwhelmingly greater section of a nation's workforce. In the Nigerian context, implementation of financial inclusion strategy is

*Email: iabafs.ng@gmail.com

${ }^{\#}$ Modified and revised version of the paper, presented in the $2^{\text {nd }}$ International Conference on Inclusive Economic Growth and Sustainable Development, SDMIMD, November 2016. 
an emerging concern in the purview of banks' regulation and supervision (Umoh, 2016). Various policies targeted at financial inclusion has so far not had the desired impact on the real sector of the Nigerian economy due to lack of access to finance, hence Nigeria still ranks low among its peers like South Africa and Kenya in financial inclusion. The positive correlation of financial inclusion and improved income, employment generation, poverty reduction, and stable financial system in an economy is widely recognized. Financial inclusion rate is higher in high-income countries than developing countries; while 89 percent of adults in the former have accounts at a formal financial institution, only 41 percent of the latter do (Ajakaiye, 2013). Thus, focused financial inclusion research is needed in the area of implementation as a way of signposting practical priorities for attaining the goals of an inclusive economic growth, especially in a resource-rich, yet poor economy like Nigeria.

As part of efforts to address the high rate of financial exclusion in Nigeria, a National Financial Inclusion Strategy (NFIS) was designed to reduce the number of adult population who are excluded from the formal financial market, from 52.5 percent in 2008 to 20 percent by the year 2020 . To this end, a number of strategic measures were embarked upon to enhance financial inclusion. These include, among other measures (Umoh, 2016), Know-Your-Customer (KYC), agent banking framework, national financial literacy programme, cashless policy, and mobile payment system, and establishing linkages between commercial banks, governments, and microfinance banks for funding micro, small and medium enterprises (MSMEs), as well as diverse credit enhancement schemes and programmes.

Against the forgoing backdrop, questions remain as to whether the measures taken so far under the NFIS have impacted positively on the capacity to achieve the set 2020 targets. Specifically, what has been the implementation results so far under the NFIS nationally and geopolitically? How has the NFIS performed in the critically important dimensions of Gender, Payments, Savings, and Credit? Less than five years to 2020, how has the NFIS worked generally? This research is designed to address these concerns so that findings could trigger desirable policy reforms, new programmes and initiatives towards attaining inclusive growth and sustainable development. It is important to track changes in national financial inclusion so as to help in designing further necessary interventions and innovations such as the manner by which M-PESA in Kenya has revolutionized the country's financial inclusion landscape.

\subsection{Statement of the Problem}

Frontier markets like Nigeria have a number of challenges compounded by wavering prosperity, corruption, arbitrary enforcement of rules and regulations (Musacchio \& Werker, 2016), but they are probably not lacking in well-conceived economic policies and strategy formulation; the problem has always bordered on policy implementation. There have been some increasing concerns that the pattern of economic development in frontier economies is often skewed towards a few rich people, leaving out the vast majority of the weaker sections of the society, whereas an economy cannot thrive sustainably on a fraction of its citizens while excluding the others (Aduda \& Kalunda, 2012). When financial development is rather exclusive, economic growth is dampened and real development stalled (Cull \& Demirguc-Kunt, 2012). Unfortunately, whereas strategy execution, monitoring and evaluation form a very critical part of any formulated strategy (Sull, et al., 2015), research to date has not given adequate attention to the concept of financial inclusion in terms of actual policy implementation in Nigeria. Focusing more on macroeconomics of financial inclusion, existing studies on financial inclusion in general have not explored the subject from strategic management angle - assessing the extent to which national initiatives and programmes and strategies have attained their set targets, with a view to making desirable policy adjustments, fine-tuning or emphasis. A recent attempt at chronicling the Central Bank of Nigeria (CBN)'s role and efforts in the implementation of NFIS since inception up to the first half of 2015 (Umoh, 2016), could not go far as to quantitatively detailing the extent to which Nigeria has moved towards attaining the 2020 financial inclusion target, hence, the present attempt aimed at filling some gaps. 


\subsection{Significance of the Study}

This work is focused on the Nigerian context, bearing in mind that the concept of financial inclusion varies with the level of countries economic development or geographic locations (Aduda \& Kalunda, 2012). Nigeria, often monikered as the Giant of Africa, is Africa's most populous country and the world's seventh largest with estimated population of 186 million (2016). The country is one of the ten countries that are expected to account collectively for more than half of the world's population by 2050 with its population currently growing the most rapidly (United Nations Economic and Social Affairs Department, 2017). The fall in oil prices and other commodities with attendant disruption of fiscal cash flows and monetary instability in the face of high unemployment rate, have made inclusive growth strategy imperative, because the country no longer enjoys the windfalls of oil revenue of the 1970s and $80 \mathrm{~s}$, hence the need to ensure that all hands are on deck to revive the economy. It therefore behooves Nigeria to take issue of financial inclusion in the development of the economic more seriously. To this end, the financial sector development is generally regarded as a prerequisite to sustainable economic growth and development in terms of helping to meet people's needs for savings, investment, payment, credit and risk management which is particularly beneficial to the poor and the generally disadvantaged groups in the society (Umoh, 2016, Ajakaiye, 2013). If the financial sector is to effectively play its critical financial intermediation role effectively and efficiently, financial inclusion research is pivotal. It is further argued that financial inclusion strategy and policy reforms should be based on reliable and comprehensive data that reflect the critical dimensions of the subject. In a nearly 200 million-people economy like Nigeria with large low-income population, financial inclusion is central to its sustainability, so as to stimulate economic activity and improve the people's overall standard of living.

Thus, by measuring and tracking financial inclu- sion drive at national and sub-national levels, policy makers, change agents, consultants, reengineering managers and other stakeholders can better understand reform priorities and incentives as well as identify strategic milestones and evaluate the progress that has been made over the recent past so as to direct resources appropriately. It is therefore expected that findings from the present study will help the Government of Nigeria, banks and other financial services operators in implementing policies and programmes that will enhance financial inclusion, thereby fostering economic growth and development. The study may also provide some useful learning curve for similar frontier economies concerned with inclusive financial system drive.

\subsection{Objectives of the Study}

In furtherance of the renewed global emphasis on sustainable inclusive development (Sachs, 2015), the main objective of this paper is to evaluate Nigeria's Financial Inclusion Strategy (NFIS) launched in 2012 as a way of gauging the effectiveness of strategic management of financial inclusion in the country. Specifically, the study aimed to:

1. Assess the overall performance of financial inclusion strategy in Nigeria, and advise on developing a strategic implementation framework for achieving greater financial inclusion in the country.

2. Appraise the achievements Nigeria's National Financial Inclusion Strategy (NFIS) geo-politically.

3. Critically evaluate the performance of the NFIS in terms of such KPIs as Gender, Payments, Savings, and Credit.

This paper is organized into five sections. After this introduction, the next section (Section two) presents the conceptual, theoretical and empirical literature review of the subject-matter including aspects of the NFIS. Section three highlights the methodology adopted for the study, while Section four presents the results and a summary of the findings. Section five concludes the paper with some policy recommendations. 


\section{Literature Review}

\subsection{Conceptual Aspects and Relevance of Financial Inclusion}

\subsubsection{Financial Inclusion}

There are many different views on what 'financial inclusion' means and entails in the literature, but the fact that 'financial inclusion' entails key aspects of access to formal financial services - payments, savings, insurance, credit, and so on - by vulnerable/low income groups at an affordable cost, is fairly unanimous. Usage and accessibility, issues of affordability (fair price), convenience ("no frills account"), timeliness, adequacy, and product knowledge, are among the perspectives emphasized in the growing body of literature on financial inclusion. Poverty eradication and inclusiveness are the core concerns of financial inclusion. Thus, financial inclusion has been described as enhancing access to financial services, whether formal or informal, at affordable cost to the unbanked (Ozughalu \& Ogwumike, 2015, Umoh, 2016, Sanusi, 2012). The issue of product knowledge in today's digital era has assumed increasing importance hence the critical role of financial literacy, counseling and capacity-development in enhancing financial penetration at the grassroots. For example, affordability does not mean that operators should ignore risks when deciding to offer services, but that efforts should be made to ensure that financial services are available to the needing populace at affordable costs and sustainably. Basically aimed at benefiting the poor majority who do not use formal financial services, financial inclusion has been defined broadly as the process of availing an array of required financial services at a fair price, at the right place, form and time, and without any form of discrimination to all members of the society (Aduda \& Kalunda, 2012). In the final analysis, for appreciable financial inclusion to happen, the vast majority of the adult population must have the capacity, skills, knowledge and understanding to make the best use of financial products and services, including mobile money accounts that may not necessarily require having an account with a financial institution (Aduda \& Kalunda, 2012).

\subsubsection{Financial Inclusion and Innovation}

Full financial inclusion implies offering every household with access to a bouquet of formal financial services including the following, among others: Bank accounts; Savings; Insurance; Payments / remittances; Affordable credit; Financial counseling. These services are traditionally provided by wide range financial institutions such as commercial banks, microfinance institutions, credit unions, mobile network operators, among others. In the world of supply-led business models, financial services operators often perceive poor customers to be high risk and low profit whereas the true situation, as pointed out by development specialists like Mercy Corps (Mercy Corps, 2016) is that we do not have enough financial services providers who are versed in adequately conceptualizing, mitigating, marketing and managing suitable financial products and services for the poor. Rich and poor customers value dependable and quick access to financial services as much as the cost. Admittedly, poorer or vulnerable populations will have limited ability to meet the formal institutions' standard requirements such as collateral KYC identification, cash flow or verifiable credit history, but this reality only goes to provide the discerning provider with humongous opportunities to develop creative Financial Inclusion Products (FIPs) that address the core financial needs of vulnerable sections of the society, delivered in age-, gender-, and context-suitable and scalable manner. And this is where microfinance fits into financial inclusion. The concept of microfinance was pioneered in Bangladesh by Professor Muhammad Yunus, who started by lending \$27 of his own money to 42 female entrepreneurs who could not get loans from the banks. Overtime a number of leading companies have adapted nonprofit business models to serve the bottom of the pyramid - a kind of Yunusm - across the world.

\subsubsection{Causes and Effects of Financial Exclusion}

The literature (Ozughalu \& Ogwumike, 2015, Aduda \& Kalunda, 2012, Aigbokun, 2013) suggests that financial exclusion - being excluded from the formal financial system complete with all the financial services that are suitable to people's needs and enable them to lead a normal life in the society in which they belong - is associated 
with loss of opportunity to grow the economy, retarded economic growth, increased poverty levels, high information and transaction costs in the financial system, an unemployment. The main reasons behind financial exclusion include illiteracy or inadequate knowledge about the role and function of banks, banking products / services, and interest rates; lack of awareness of banking terms and conditions; high transaction costs; lack of acceptable identifier; access issues such as proximity, cost, marketing bias, and negative experiences. The consequences of financial inclusion, as documented by many authors (Ozughalu \& Ogwumike, 2015, Aduda \& Kalunda, 2012) include: low savings, slow or no growth, low business investment, breeding social exclusion, which heightens social classes, divisions, polarized societies that are unhealthy for the economy, and the fact that, in the current dynamic digital world, those not having access to essential financial services are likely to suffer more serious consequences now than in the past.

\subsubsection{Financial Inclusion is Multidimensional and Dynamic}

Financial inclusion concept is generally regarded as multidimensional and dynamic from the following lenses: its being associated with diverse socioeconomic, cultural and geographic aspects; its being rooted in social exclusion which encompasses social, political, cultural, economic, and technological dimensions; its impact on people in several ways and to varying degrees over time, and the caution for stakeholders not to examine financial inclusion issues in isolation of other relevant facets of development - such as non-financial capital types: physical, natural, human, and social (Aduda \& Kalunda, 2012). All the forgoing dimensions underscore the imperative of holistic approach to financial inclusion.

\subsubsection{Major Barriers and Options for Effective Financial Inclusion}

Factors responsible for the low rate of financial inclusion in Nigeria - gender issues, lower level of education, poverty, affordability, eligibility, physical access, religious factors, lack of trust and so on - been documented (Ajakaiye, 2013); the main concern of this paper is about how to reverse the situation faster towards financial inclusion. In this context, there are diverse strategies for enhancing financial inclusion; these range from profit-oriented to non-profit/social development perspectives (Yunus et al., 2015). Some of the latest strategies for boosting financial inclusion particularly in developing economies have also been well documented (Mercy Corps, 2016) and these include, among others, the use of smart subsidies and financing, promotion of appropriate (pro-poor) products and services, increasing client-level financial capability (combination of financial skills, knowledge and behaviours needed to make informed and effective financial decisions), integration of technology and digital finance, strengthening financial market institutions and regulations, facilitating appropriate financing mechanisms and new delivery methods, and continuous solution-driven research and reiterative analysis.

\subsubsection{Tracking Strategy Implementation}

Measuring and tracking financial inclusion is crucial for identifying reform priorities and incentives as well as identifying strategic milestones progress attained overtime. Financial inclusion indicators can be very diverse and numerous indeed, as shown by Brookings 2015 Financial and Digital Inclusion Project (FDIP) report on 21 frontier economies based on 33 indicators across four broad dimensions, namely, country commitment, mobile capacity, regulatory environment, and adoption (Idowu, 2016). In this study, guided by the theory of change which lies in the ability to demonstrate progress towards targets (Ajakaiye, 2013, Taplin, 2013), the relevant indicators for this purpose have been classified into four: Access (ability to use financial services/products), quality (relevance of financial service/product), usage (permanence and depth of financial service), and impact (changes in the lives of consumers attributable to the use of financial device/product/service). While all these parameters are crucial to tracking financial inclusion, the emphasis in the present analysis is access and usage-driven. In this context, several indicators in the index of financial inclusion include demographics, branch penetration, ATM penetration, loan penetration, and so on. However, it is important to stress that mere ownership of a financial product or device does not mean financial inclusion rather it is the actual usage of 
the financial service that ultimately delivers the benefit of financial inclusion - economic empowerment and self-reliance.

\subsubsection{Key Performance Indicators (KPIs)}

Basic financial services or products for financial inclusion purpose include payment, savings, credit, insurance and pension, while the contemporary channels for delivering or distributing these fundamental financial products including bank branches, Automated Teller Machines (ATMs), Points of Sale (PoS), and Agents (Central Bank of Nigeria annual economic report, 2014). Availability and ease of savings and payment system in particular facilitate exchange, and exchange is the crucial process by which mankind prospers and progresses (Frisby, 2014).

\subsubsection{Enhancing Mobile Capacity for Financial Inclusion}

There is some noticeable correlation between financial inclusion and the degree of people access to affordable financial infrastructure or new technology. Of the seven billion people in the world, only around two billion are banked and participate in e-commerce, yet about 5 billion have at least some access to the internet (Frisby, 2014). It is estimated that advanced mobile technology will be globally ubiquitous by 2020 with 70 percent people using smartphones and 90 percent mobile broadband networks, and it is in this context that the role of mobile money (M-Pesa), bypassing traditional banking, in accelerating financial inclusion in Kenya is well documented (Frisby, 2014). Mobile money has the advantage of ease of use, but its efficacy is still subject to internet connectivity, mobile phone coverage and affordability of the mobile phones. Of course, there are all sorts of concerns for mobile money - money-laundering, tax, etc. - but such concerns are also applicable to traditional banking approaches that have kept millions of rural folks out of the mainstream financial system. Thanks to M-Pesa, financial inclusion is estimated to be at 80 per cent in Kenya and M-Pesa reportedly launched in Tanzania, South Africa, India, Afghanistan, and Eastern Europe. Evidently, the monetary and payment monopoly that banks have enjoyed for so long is under threat from more efficient payment systems like M-Pesa. The Central Bank of Nigeria (Central Bank of Nigeria annual economic report, 2014) suggest that the Kenyan payments system (simple, cheap way to transfer money) should be replicated as the model for enhancing financial inclusion in Africa, especially considering that majority of Africans live in villages. It is expected that, through the instrumentality of the Smart Nigeria Digital Economy Project, the financial services within the country's digital economy can add US\$88 billion and create over three million new jobs over the next ten years (Enelamah, 2017).

\subsection{Theoretical Literature}

There is a multiplicity of explanations for the growing socio-economic importance of financial inclusion. The Finance-Growth Theory, Financial IntermediationFinancial Stability Theory, and the Theory of Change (ToC) represent the broad perspectives that have been frequently voiced in diverse academic, religious, political and international development policy and practice circles (Demirguc-Kunt, et al. 2015, Ozughalu \& Ogwumike, 2015, Umoh, 2016, Cull \& Demirguc-Kunt, 2012, Ajakaiye, 2013, Mercy Corps, 2016, Taplin, 2013, Anderson, 2005, Coryn et al., 2011). Finance-Growth Theory refers to the imperatives and arguments for or against finance-led inclusive growth, social equality and justice: It is contended that reducing inequality and increasing degrees of inclusiveness through financial inclusion initiatives can lead to a process of strong and sustained growth and efficient delivery of social security benefits to the under-privileged sections of the society. Financial exclusion is part of social exclusion, hence, ensuring that the national economy is managed in a way as "to secure the maximum welfare, freedom, and happiness of every citizen on the basis of social justice and equality of status and opportunity" is a fundamental objective and directive principle of the Government of Nigeria (Constitution of the Federal Republic of Nigeria, 1999). Studies have revealed that countries with high rate of financial exclusion (26-48 \% and above) showed higher poverty ratios measured by both national and international poverty lines, hence financial inclusion is a prerequisite to economic development (Demirguc-Kunt, et al. 2015, Aduda \& Kalunda, 2012). 
Financial Intermediation-Financial Stability Theory refers to concerns for financial sector development, looking at financial intermediation - the extent to which financial institutions bring deficit spending units and surplus spending units together - as critical tool for inclusive economic development. The proposition is that a greater participation of workers of all vocations in overall productivity growth will not only lead to social protection of the poor for poverty alleviation, but also for strengthening the dynamics of domestic markets particularly in terms of monetary stability. Lack of access to finance has been severally associated to persistent income inequality, unemployment, poverty traps, and lower growth (Aduda \& Kalunda, 2012, Morebise, 2017). Relatedly, financial stability is the state where financial intermediation process works smoothly while financial instability is characterized by financial markets shocks and volatility as frequently experienced in developing economies like Nigeria. Thus, sustained and creative development of the financial sector or soundness of the financial sector as a whole as the veritable platform for availing a bouquet of needed financial services at a fair price, at the right place, form and time and without any form of discrimination to citizens, is seen as pivotal to inclusive growth. Financial stability, effectiveness of monetary policy implementation, financial resilience, and financial inclusion can be enhanced through tiered banking system, ease of entry and exit of operators, efficient national payment system, existence of foreign-owned banks and effective deposit insurance (DemirgucKunt, et al. 2015, Aduda \& Kalunda, 2012, Yakubu \& Adua, 2015, Kolawole et al., 2017).

Emerging in the 1990s as a methodological model and evaluate comprehensive community initiatives, the ToC (An Introduction to the theory of change, 2016, Theory of change, 2016) explains the need to define strategic, longterm goals by stakeholders as a prerequisite for change and then mapping backwards to identify the conditions precedent to attaining the desired change As detailed by Anderson (Anderson, 2005) the ToC idea is that a set of early and medium-term accomplishments prepares the stage for achieving long-term results. Creating a honest strategic picture of the steps or interventions needed to reach a goal, the ToC is also an expectation management tool requiring that a distinction is made between desired and actual outcomes, and modelling the desired outcomes before any forms of intervention is decided.

The foregoing theoretical perspectives are arguably interrelated: you need a theory of change as a tool for developing solutions to such a complex socio-economic problem as financial inclusion, and you cannot have inclusive growth without using financial inclusion and market development as a means to achieving the vision of an inclusive, stable society. Strategy without its conscientious implementation is meaningless. Hence, the present contribution is based on a 'holistic' doctrine of financial inclusion founded on the core objective of responsible governance - sustainable growth and social justice.

\subsection{Empirical Literature}

\subsubsection{Nigeria's Financial Inclusion Strategy (NFIS)}

A richly endowed country and one of the ten most populous nations in the world, Nigeria is among the largest exporters of crude oil, a major cocoa exporter and one of the largest producers of bitumen, steel, coal, to mention a few. The country's huge natural assets include very large arable land and good forest reserves. However, regrettably, Nigeria is currently classified (DemirgucKunt, et al. 2015) 'lower middle income' economy with 96.6 million adult ( 15 years and above) population with Gross national Income (GNI) per capita of US\$2, 710. The Central Bank of Nigeria (CBN) as the custodian of the financial system in the country, acknowledges executable and achievable financial inclusion strategy as a crucial lever to achieving its mandate of financial system stability and growth (Sanusi, 2012; Fatokun, 2013). Consequently, the National Financial Inclusion Strategy (NFIS) of Nigeria, launched on October 23, 2012, was aimed at reducing the percentage of adult Nigerians excluded from financial services from 46.3 percent in 2010 to 20.0 percent by 2020 . The key interventions are expected through the targets detailed in section four of this paper.

The implementation process has been largely collaborative, involving not only the Deposit Money 
Banks (DMBs), but other key stakeholders, notably, National Insurance Commission, the national Pension Commission, Securities and Exchange Commission, the Nigeria Deposit Insurance Corporation, the Federal Ministries of Finance and Communications Technology, the National Communications Commission, as well as state governments with high exclusion rates (ERs), notably, Kano (77\%), Jigawa (70\%), Ogun (49\%), Cross River (37\%), and Rivers (37\%), among others (Central Bank of Nigeria annual economic report, 2014). The collaborative efforts have resulted in a wide range of initiatives and reforms such as in the inclusion of the informal sector in contributory pension scheme under the new 2014 Pension Reform Act, optimal pricing of mobile payment services by mobile network operators, extending deposit insurance coverage to subscribers of mobile money, thereby boosting market usage and confidence, and the Securities and Exchange Commission's capital market master plan (2015-2025) that includes financial inclusion objectives (SEC Nigeria, 2014).

Based on the CBN's report (Central Bank of Nigeria annual economic report, 2014), various collaborative efforts mentioned earlier in the introduction, have resulted in a wide range of initiatives and reforms such as in the inclusion of the informal sector in contributory pension scheme under the new 2014 Pension Reform Act. The Act also makes it mandatory for state governments to do the same; optimal pricing of mobile payment services by mobile network operators, fostering best service availability and experience; extending deposit insurance coverage to subscribers of mobile money, thereby boosting market usage and confidence; the Securities and Exchange Commission's capital market master plan that includes financial inclusion objectives and setting up a Financial Inclusion Division within the Agency; launching of the National e-ID card in August 2014 by the National Identity Management Company, providing identification numbers to enhance savings and payments including government's welfare benefits; enabling NIPOST to provide financial services as agents of deposit money banks (DMBs) under a new bill initiated by the Federal Ministry of Communications Technology; promotion of invest- ment in long distance fibre optic cables from where mobile network operators (MNOs) and other stakeholders could draw requisite connectivity for their operations; and geospatial mapping of financial services access points in Nigeria (SEC Nigeria, 2014). It remains to be seen how these activities have, in concrete terms, facilitated the achievement of the set target for financial inclusion in the economy by 2020 .

\subsubsection{Banks' Financial Inclusion Initiatives and Programs}

Financial inclusion programmes prevalent in the Nigerian banking system are basically in the following areas (Central Bank of Nigeria annual economic report, 2014): Institutionalisation of financial inclusion as a corporate strategy; roll-out of specific products that facilitate savings mobilization from different customers; implementation of tiered KYC framework, easy account opening procedures, and customer identification using biometric solutions; target-setting for ATM and PoS growth; financial literacy campaign and public education on financial products; establishment of customer help-desks for resolving disputes and reinforcing confidence; implementation of mobile money services in partnership with MNOs; and implementation of agent banking system.

\subsubsection{Overall Status of NFIS}

Following recent reviews (Central Bank of Nigeria annual economic report, 2014, Central Bank of Nigeria. Financial Inclusion Newsletter, 2017, EFInA, 2016, EFInA, 2017), the status of NFIS can be summarized as follows: Nigeria's financial exclusion rate declined from 52.5 percent in 2008 to 41.6 per cent in 2016, but, clearly, more work is needed to be done if the target of 20.0 per cent by 2020 is to be realized. While there has been consistent growth in the number of adults banked, from 21.1 percent in 2008 to 38.3 percent in 2016, gender-wise, about 55 percent of the total adult female population remained financially excluded. Up to 65 per cent of the rural adult population remained financially excluded in 2016. Exclusion is currently highest among ages 18-25 years and above 56 years. Geo-politically, exclusion rate is highest in North-West $(70 \%)$ while it is lowest in the South-West (18\%). 


\subsubsection{Review of Related Studies}

Financial inclusion is widely seen as pivotal to poverty eradication and inclusive economic development and it is no surprise that many researchers have examined its ramifications from diverse angles - notably, scope, components, impact, models, and measurement. However, as earlier noted, in the Nigerian context, existing studies on financial inclusion have not explored the extent to which national initiatives and programmes and strategies have attained their set targets, as a basis for determining areas for emphasis in the review of financial inclusion implementation strategy. In this context, a major burning issue is on whether or not full financial inclusion is a possibility or simply unattainable. This is a difficult question to answer considering the multidimensionality of financial inclusion and the plethora of indicators that have to be deployed in attempting to answer it. Hence, Aduda and Kalunda, attempting to identify the relationship between financial inclusion and financial stability, opine that enhanced measures of financial inclusion in terms of usage and access do impact financial stability in developing economies like Kenya. A similar study (Kolawole et al., 2017) supports the view that growing would improve the effectiveness of monetary policy. This means that concerted efforts should be made to integrate informal financial services into the formal financial system.

Research has also been concerned about the dearth of information on the narrower issues of business and financial structures of informal enterprises without which the desired integration of the informal sector into the formal financial system would remain problematic. Thus, against the general focus on the broad-based development of the informal sector, another study (Oladejo et al., 2014) proposed and characterized hexagonal structure articulation approach - based on aspects of business organization, production, cash flow, capitalization, technology, and financing - as a way of enhancing research to gain robust understanding of the informal enterprises in Nigeria towards achieving inclusive and sustainable financial sector.

Typical of many commodities-dependent developing economies, Nigeria is currently in the process of accumulating more and more external debt (US\$30 billion) to finance her fiscal deficits and huge socio-economic desires, whereas it has been empirically established that productively and financially developed economies experienced low accumulation of external debt (Chuku, 2013). Hence, it is stressed that all efforts should be made to improve access to credit by micro, small and medium enterprises (MSMEs) so as to move majority of entrepreneurs out of poverty (Evbuomwan et al., 2013). Indeed, it can be argued that what Nigeria really needs more than debt accumulation is intensification of small business-oriented financial inclusion strategy implementation to strengthen its financial market.

An economic study on inclusive growth and poverty reduction in Nigeria (Ozughalu \& Ogwumike, 2015) shows that the country has not experienced inclusive growth over the years despite impressive economic growth over the years. The research attributed the situation to macroeconomic factors such as the poor performance of the manufacturing sector, weak knowledge base, poor human capital development and low level of global competitiveness.

Research has also looked at the peculiar nature of financial inclusion measures including 'supply-side' and 'demand-side' measures detailed by Ajakaiye (2013), encompassing different parameters that are reflective of the subject country's local peculiarities, diversity and complexity. The paper notes that males are more financially included $(47.4 \%)$ than females $(38.3 \%)$ and that Nigeria performs relatively lower than South Africa, Namibia, and Botswana in financial inclusion drive.

\subsection{Contribution to Knowledge}

This work attempts to shift the financial inclusion research slightly away from surfeit of social science emphasis into some management science realm with emphasis on strategic management. As earlier noted, extant financial inclusion research works have examined several dimensions, philosophy and scope of financial inclusion, but fewer academic papers have focused on its strategic implications for change management in a world that is constantly in a state of flux (Hindle, 2008). The present contribution is significant in terms of its strategic management underpinning 
(as opposed to the traditional macroeconomic), its relatively wider coverage (to include geopolitical analytics), and the use of multiple data from both domestic and international sources. Given that financial sector development is crucial for sustainable economic growth through its veritable financial intermediation role, financial inclusion research in the Nigerian context needs to go beyond macroeconomics to identifying the gaps in strategy implementation so that appropriate, practical incentives and capacities can be designed to achieve the longstanding vision of a prosperous Nigeria. Thus, the dearth of academic papers focused on strategic management perspective of financial inclusion strategy implementation in Nigeria constitute the motivation for the present contribution aimed at generating knowledge on the implementation of the NFIS and providing insights into areas of possible financial inclusion reforms and priorities in the near-term.

\section{Methodology}

\subsection{Research Questions}

1. Bearing in mind the 2020 target for financial inclusion, what is the overall performance of the NFIS and what is advisable as part of a national strategy for developing greater financial inclusion in Nigeria?

2. To what extent has the country's National Financial Inclusion Strategy (NFIS) achieved its targets geopolitically?

3. How has the implementation of the NFIS faired in terms of Gender, Payments, Savings, and Credit penetration?

\subsection{Data and Analysis}

The present study is a retrospective analysis of Nigeria's Financial Inclusion Strategy (NFIS) launched in 2012, based on reading the NFIS documents and analyzing available data spanning 2008 to 2016 sourced from the Global Financial Inclusion (Global Findex) database, Central Bank of Nigeria, and Enhancing Financial Innovation and Access (EFInA), analyzed using descriptive statistics.

The 2014 Global Findex database (Demirguc-Kunt, et al. 2015) provides in-depth comparable indicators of how people across the world save, borrow, make payments, and manage risk, and is perhaps the most comprehensive set of data on the subject. The indicators were based on interviews with 150,000 nationally representative and randomly selected adults age 15 and above in more than 140 countries including Nigeria. It is noted that the Global Findex data do not cover international remittances which is economically important for a developing economy like Nigeria, hence the need to include other data perspectives in this paper.

The EFInA, one of Nigeria's leading organizations promoting Financial Inclusion in Nigeria, released its 2016 biennial Financial Inclusion Survey data on the $30^{\text {th }}$ of March 2017. The 2016 survey covered 23,000 adults across all 36 states of the country including the Federal Capital Territory. The country's total adult population (18 years and above) is estimated at 96.4 million out of which 61.9 percent (59.6 million) are based in rural areas, while only 4.2 percent derive their main source of income from the formal sector.

Guided by the Theory of Change (ToC) which lies in the capacity to demonstrate tangible progress on the achievement of targets so that evidence of success will confirm the theory and indicative of strategy effectiveness (Taplin, 2013), the relevant indicators assessed in this study have been focused broadly on access and usage. Financial inclusion has been measured from both supply side (4 indicators) and demand side (5 indicators). The demand side refers to the use of financial products and services, while the supply side captures measures bordering on access to finance. Thus, following Ajakaiye, nine key indicators are examined in this paper, namely, payments, savings, credit, insurance, pension, branch penetration, ATM penetration, PoS penetration, and spread of bank agents. This theorybased approach helped the study to be focused on key concerns and practical dimensions of financial inclusion as a desirable socio-economic change process.

As stated earlier, data were sourced from the public domain, namely, CBN and the World Bank's Global Findex (Demirguc-Kunt, et al. 2015) capturing how adults in 140 countries save, borrow, make payments, 
and manage risk in 2014; this is complemented with the Enhancing Financial Innovation and Access (EFInA) survey details. EFinA, tries to promote financial inclusion in Nigeria and has conducted biennial surveys of adults of 18 years and above since 2008. The National Bureau of Statistics (NBS) weights EFInA's survey results to provide for the total adult population, bench marked to national population estimates for verification.

Tables and graphs were used to show the trend and behaviour of key variables at different periods of time and different regions in the country.

Assessment of the specific achievements towards the set 2020 targets under the Nigeria's NFIS was based on the nine KPIs selected from the literature (Ajakaiye, 2013). The multi-source approach is expected to help policy makers to assess the plausibility, feasibility, testability and accountability of set targets, as prescribed by Kubisch (Kubisch, 1997) and others.

\section{Results and Discussion}

\subsection{Data Harmonization}

Data harmonization of the three major data sources was done to periscope the implied variances to the 2020 NFIS targets, as shown in Table 1.

Table 1. Percentage of Adult Nigerians Financially Excluded (2014) Harmonizing the multiples sources of data

\begin{tabular}{lll}
\hline Data Sources & $\begin{array}{l}\text { \% Financially } \\
\text { excluded }\end{array}$ & $\begin{array}{l}\text { Variances to 2020 NFIS } \\
\text { target of 20\% }\end{array}$ \\
\hline Global Findex & 44.4 & -24.4 \\
CBN & 60.5 & -40.5 \\
EFInA & 39.7 & -19.7 \\
Average & $\underline{48.2}$ & -28.2 \\
\hline
\end{tabular}

[Source: Author's analysis (2017)]

The results displayed in Table 1 suggest that, on the average, roughly half of Nigerian adults were financially excluded in 2014. The situation has only marginally improved as shown in Table 2 and Figure 1. The evidence has shown that Nigeria's level of financial exclusion currently averages at 48.2 percent compared to the 2020 target of 20 percent. This means that prog- ress on implementation of financial inclusion strategy in Nigeria has not measured up to the performance of similar Sub-Saharan economies like South Africa and Kenya which have 13 percent and 17 percent exclusion rates in 2015 and 2016 respectively (Ajakaiye, 2013, EFInA, 2016).

Table 2. Number and percentage of adult population excluded in Nigeria 2008-2016

\begin{tabular}{lll}
\hline Year & $\begin{array}{l}\text { Adult Population Excluded } \\
\text { (million) }\end{array}$ & \% Adults Excluded \\
\hline 2008 & 45.4 & 52.5 \\
2010 & 39.2 & 46.3 \\
2012 & 34.9 & 39.7 \\
2014 & 36.9 & 39.5 \\
2016 & 40.1 & 41.6 \\
2020 target & & 20.0 \\
\hline
\end{tabular}

[Source: EFInA, 2017]

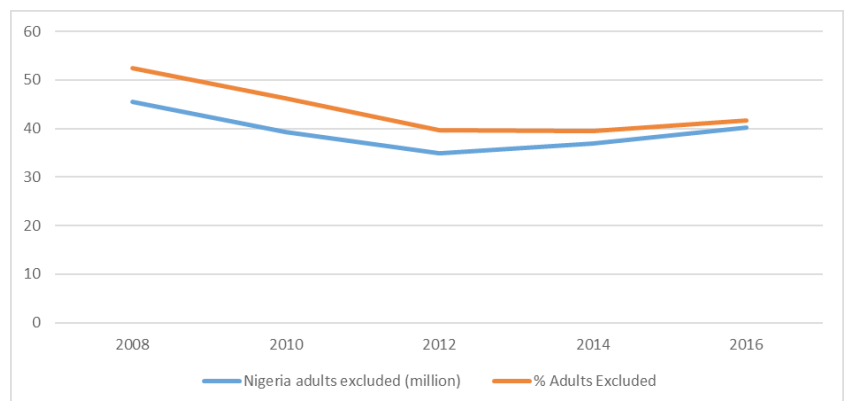

Figure 1. Trend of Number and percentage of Nigerian adults excluded 2008-2016.

\subsection{Nigeria's Financial Inclusion Strategy: An Overview of Status, 2010-2016}

Table 2 displays the overall picture of the achievements from the implementation of the NFIS so far (2010-2016) based on the nine KPIs selected for this study. The evidence in Figure 2 suggests the need to double-up actions particularly in the areas of ATM and PoS services where the financial inclusion gap (variance) is widest among the KPIs, at -188 , and -707 .

Happily, from Table 3, it can be seen out of the nine major KPIs, expansion of banks' branches and agency banking are two indicators that have recorded high level achievement ( -2 and +19 respectively) towards meeting the respective 2020 targets. 
Table 3. Implementation of Nigeria's Financial Inclusion Strategy, 2010-2016

\begin{tabular}{llllllll}
\hline S/No & KPIs & 2010 & 2012 & 2014 & 2016 & 2020 Target & Variance to 2020 Target \% \\
\hline 1 & \% adult using a payment product & 22.0 & 20.0 & 24.0 & 38.0 & 70.0 & -32 \\
2 & \% adult using a savings product & 24.0 & 25.0 & 32.0 & 36.0 & 60.0 & -24 \\
3 & \% adult using a credit product & 2.0 & 2.0 & 3.0 & 3.0 & 40.0 & -37 \\
4 & \% adult using an insurance product & 1.0 & 3.0 & 1.0 & 1.0 & 40.0 & -39 \\
5 & \% adult using a pension product & 5.0 & 2.0 & 5.0 & 5.0 & 40.0 & -35 \\
6 & No. of Bank Branches per 100,000 adults & N.A. & N.A. & 5.9 & N.A. & 7.6 & -2 \\
7 & No. of ATMs per 100,000 adults & N.A. & N.A. & 15.2 & N.A. & 203.6 & -188 \\
8 & No. of PoS per 100,000 adults & N.A. & N.A. & 143.3 & N.A. & 850.0 & -707 \\
9 & No. of Agents per 100,000 adults & N.A. & N.A. & 80.7 & N.A. & 62.0 & 19 \\
10 & Financial Exclusion & 46.3 & 39.7 & 39.5 & 41.6 & 20.0 & -22 \\
\hline
\end{tabular}

[Sources: Sanusi, 2012, Central Bank of Nigeria annual economic report, 2014, EFInA, 2016]

N.A.: Data not available

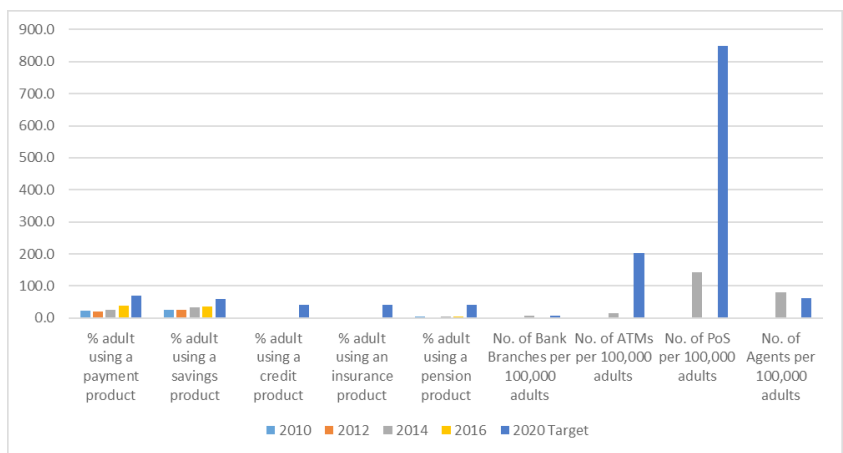

Figure 2. Nigeria's Financial Inclusion Strategy: An Overview of Status, 2010-2016.

\subsection{Financial Inclusion in Nigeria by Geopolitical Regions}

Figure 2 and Table 4 presents the financial exclusion rates in Nigeria by geopolitical zones, from 2012 to 2016. The results show that the Northern geopolitical zones of the country have higher level of financial exclusion, compared with the Southern regions. Of all the geopolitical zones, only the South West has experienced positive variance; the zone had the lowest exclusion rate of 18 percent in 2016, thus already surpassing the 20 percent exclusion rate target under the NFIS. There was a marginal decline in the exclusion rate in the South-South, from 33 percent in 2014 to 31 percent in 2016, while the South East witnessed a slight increase in exclusion rate from 25 percent in 2014 to 28 percent.

On the other hand, it is shown that, at 70 percent, the North-West geopolitical zone comprising Sokoto, Kebbi, Zamfara, Katsina, Kano, Jigawa, and Kaduna
States had the highest level of exclusion rate in 2016. This is a surprising development, after the same region had made some commendable improvement with its financial exclusion rate dropping from 63.8 per cent to 56.0 percent between 2012 and 2014; that is about 12 per cent progress. Interestingly, the North East, which had a worsening exclusion rate from 60 percent in 2012 to 68 percent in 2014, witnessed a decline to 62 percent in 2016. Perhaps the improvement reflects the improved security in the region following the renewed fight against the Boko Haram insurgency by the new Buhari Administration.

Table 4. Financial Exclusion in Nigeria by Geopolitical zones, 2012 $-2016$

\begin{tabular}{lcccll}
\hline $\begin{array}{l}\text { Geopolitical } \\
\text { Zone }\end{array}$ & 2012 & 2014 & 2016 & $\begin{array}{l}\text { 2020 } \\
\text { Target }\end{array}$ & $\begin{array}{l}\text { Variance to } \\
\text { 2020 Target }\end{array}$ \\
\hline North West & 64.0 & 56.0 & 70.0 & 20.0 & -50 \\
North East & 60.0 & 68.0 & 62.0 & 20.0 & -42 \\
North Central & 32.0 & 33.0 & 39.0 & 20.0 & -19 \\
South West & 25.0 & 25.0 & 18.0 & 20.0 & 2 \\
South East & 26.0 & 25.0 & 28.0 & 20.0 & -8 \\
South-South & 30.0 & 33.0 & 31 & 20.0 & -11 \\
\hline
\end{tabular}

[Sources: Central Bank of Nigeria. Financial Inclusion Newsletter, 2017, EFInA, 2016]

\subsection{Key Performance of the NFIS So Far in Terms of the Penetration of Critical Financial Services such as Gender, Payments, Savings, and Credit?}

\subsubsection{Gender Inclusivity}

Gender and age are matters of importance in financial inclusion especially in developing economies. Table 5 
shows the distribution of ownership of formal financial account in Nigeria between 2011 and 2016. While there has been some improvement in financial inclusion among women in $2016(42.6 \%)$ relative to the situation in 2011 (34.0\%), a large majority (55.4\%) of the total adult female population remained financially excluded. Up to 65.3 per cent of the rural adult population remained financially excluded in 2016. Exclusion is currently highest among ages 18-25 years.

Table 5. Distribution of ownership of formal Financial account in Nigeria, $2011-2016$

\begin{tabular}{|c|c|c|c|c|}
\hline Indicators & 2011 & 2012 & 2014 & 2016 \\
\hline All Adults & $29.7 \%$ & $43.0 \%$ & $44.4 \%$ & 48.6 \\
\hline Women & N.A. & N.A. & $34.0 \%$ & 42.6 \\
\hline $\begin{array}{l}\text { Young Adults (18 - } 25 \\
\text { years) }\end{array}$ & N.A. & N.A. & $35.7 \%$ & 37.6 \\
\hline $\begin{array}{l}\text { Adults living in rural } \\
\text { areas }\end{array}$ & N.A. & N.A. & $39.4 \%$ & 34.7 \\
\hline
\end{tabular}

[Sources: Demirguc-Kunt, et al. 2015, Ajakaiye, 2013, Central Bank of Nigeria annual economic report, 2014, EFInA, 2016]

N.A.: Data not available

The reasons for the country's high level of financial exclusion, alluded to in the literature, includes the gender issues, bankers' perception that the poor are not bankable, poverty, complicated paper work, preference for individual account as against collective accounts and the demands for physical collateral and financial illiteracy (Ozughalu \& Ogwumike, 2015, Ajakaiye, 2013, Yunus et al., 2015, Eluhaiwe, 2013). Genderwise, only 42.6 percent of Nigerian women were banked in 2016, compared to the global average of 58 percent during the same year (Demirguc-Kunt, et al. 2015).

\subsubsection{Payments Services and Digital Inclusion}

Demonetization, mobile telephony and digital banking - covering cash-in, cash-out, electronic transfers, bill payments, pre-approved credit lines, micro-credits, m-health, m-insurance, m-Agric., and so on , generally form a critical part of NFIS because of the associated convenience and cost effectiveness, serving mostly as substitute for cash payments. Moreover, mobile money promises to big business in Africa and globally; by 2030, two billion people without a bank account today will be storing money and doing remittances with their phone (Manlan, 2017, Mangena, 2016). Table 6 provides a picture of the extent of digital penetration in Nigeria in terms of ownership and use of mobile and digital accounts in the country between 2011 and 2016. It is acknowledged (Fatokun, 2013) that mobile payment operations have been live in Nigeria since November 2011 with 6.9 million transactions valued at $\mathrm{N74.3}$ billion as of May 2013. Notwithstanding, the evidence in Table 5 suggests that, while the ATM has become a major mode for funds withdrawal in the financial system (from $40.8 \%$ of adults in 2011 to $70.5 \%$ in 2014), the same cannot be said about ownership and use of mobile accounts, debit cards, credit cards, and Internet which remain at abysmally low levels of 2.3 percent, 14.1 percent, 1.9 percent, and 3.3 percent respectively as of 2014. The use of mobile money in particular has remained abysmally low at 1.3 -2.3 percent between 2014 and 2016.

Table 6. Digital Inclusion Strategy: Ownership and use of mobile and digital accounts in Nigeria 2011 - 2016 (\% of Adults)

\begin{tabular}{llll}
\hline Indicators & $\begin{array}{l}2011 \\
(\%)\end{array}$ & $\begin{array}{l}2014 \\
(\%)\end{array}$ & $\begin{array}{l}2016 \\
(\%)\end{array}$ \\
\hline Mobile accounts & 18.6 & 2.3 & 1.3 \\
Has debit card & 35.6 & N.A. \\
ATM is the main mode of withdrawals & 40.8 & 70.5 & N.A. \\
$\begin{array}{l}\text { Used debit card to make payment } \\
\text { Used a credit card to make payment }\end{array}$ & N.A. & 14.1 & N.A. \\
$\begin{array}{l}\text { Used the Internet to pay bills or make } \\
\text { purchases }\end{array}$ & N.A. & 3.9 & N.A. \\
\hline
\end{tabular}

[Sources: Demirguc-Kunt, et al. 2015, Ajakaiye, 2013, Central Bank of Nigeria annual economic report, 2014, EFInA, 2016]

N.A.: Data not available

Though fairly better than the global average of 1.0 percent, the low level of digital banking penetration in Nigeria (1.3-2.3 \%) is attributed to epileptic power supply, poor telecommunication connectivity, and inadequate synergy between mobile payment operators and the telecommunication companies. It is known that, in Sub-Sahara Africa, mobile money accounts drive the growth in financial inclusion, so much so that Africa has been regarded as the next big economic success story (Theory of change, 2016). Nigeria therefore needs to intensify its mobile money market to catch up with the rest of frontier markets, East Africa in particular, where Kenya has the largest share of adults with mobile money account and over 170,000 mobilemoney agents in the country (Demirguc-Kunt, et al. 
2015).

\subsubsection{Savings Account}

Table 7 displays the pattern of ownership of savings account at financial institutions in Nigeria $2011-2016$. The result suggests that while most people (68-69\%) tend to be prudent enough to save for one reason or the other, much fewer Nigerian adults (41.4\%) owned and used formal savings accounts in 2016. Stepping up financial literacy programmes as suggested by Eluhaiwe, 2013, among others, could help to redress this development.

Table 7. Ownership of savings account at Financial institutions in Nigeria 2011 - 2016 (\% of Adults)

\begin{tabular}{|c|c|c|c|}
\hline Indicators & $2011(\%)$ & $2014(\%)$ & $2016(\%)$ \\
\hline $\begin{array}{l}\text { Saved at a financial } \\
\text { institution }\end{array}$ & 23.6 & 27.1 & 41.4 \\
\hline Saved any money & N.A. & 69.0 & 68.0 \\
\hline
\end{tabular}

\subsubsection{Credit Facilities}

Table 8 displays financial inclusion in Nigeria through the lens of credit facilities between 2011 and 2016. Evidently, while more adults have obtained formal loan accounts during the study period (from $2.1 \%$ in 2011 to $5.5 \%$ in 2016), this achievement pales into insignificance when compared to the much higher level of adults that borrowed from family and friends (76.3\%).

Table 8. Use of formal credit facilities in Nigeria 2011 - 2016 (\% of Adults)

\begin{tabular}{llll}
\hline Indicators & $2011(\%)$ & $2014(\%)$ & $2016(\%)$ \\
\hline Borrowed from a financial institution & 2.1 & 5.3 & 5.5 \\
Borrowed from family and friends & N.A. & 37.5 & 76.3 \\
\hline
\end{tabular}

[Sources: Demirguc-Kunt, et al. 2015, Ajakaiye, 2013, Central Bank of Nigeria annual economic report, 2014, EFInA, 2016]

N.A.: Data not available

The Nigerian credit market is stymied by myriad of challenges, notably, dearth of long-term funding and information asymmetries between financial providers and the 'poor' consumers (Dutse, 2017). It has earlier been noted that countries with higher levels of domestic credit to private sector also experience higher rate of financial inclusion (Ajakaiye, 2013), hence, it is important for stakeholders to address this issue more seriously if the NFIS 2020 target is to be achieved, hence the recent establishment of Development Bank of Nigeria is seen as a step in the right direction (Ministry of Budget \& National Planning, 2017, Thomas, 2017).

\subsubsection{Summary of Findings}

The key results of this study are as follows:

1. While Nigeria's financial exclusion rate has reduced from 52.5 percent in 2008 to 41.6 percent in 2016, more than half (55.4\%) of the female adult population still remained excluded, compared to the target of 20 percent by the year 2020 .

2. The South-West geopolitical zone has surpassed the 20 percent exclusion rate target, but the remaining regions, particularly in the North, recorded various levels of financial exclusion.

3. While the ATM has become a major mode of funds withdrawal by account holders (increasing from $40.8 \%$ of adults in 2011 to $70.5 \%$ in 2014), persisting inadequacy of the number of ATMs per 1000 adults has continued to be obstructive to financial inclusion targets. Also, while more adults have obtained formal loan accounts during the study period (from $2.1 \%$ in 2011 to $5.5 \%$ in 2016), this achievement pales into insignificance when compared to the much higher level of adults that borrowed from family and friends (76.3\%). Moreover, also while most people (68-69\%) save, fewer Nigerians $(41.4 \%)$ use the formal savings facilities and products, while the use of mobile money has remained abysmally low at 1.3-2.3 percent in 2014 and 2016 respectively. Thus, out of the nine major KPIs emphasized in this study, expansion of banks' branches and agency banking are two indicators that have recorded high level achievement $(-2$ and +19$)$ towards meeting the respective 2020 targets.

The current findings in the Nigerian context, broadly indicate sub-optimal performance, when compared with the experiences of other transitional economies like Botswana, Namibia, Kenya, Ghana, and India, where affirmative action, rapid growth of mobile money, financial literacy, business-friendly environment, and general deepening of the financial system, among other critical success factors, characterize 
effective financial inclusion strategy (Ajakaiye, 2013, Idowu, 2016, Morebise, 2017, Manlan, 2017).

\section{Conclusion}

The study reviewed the implementation of Nigeria's Financial Inclusion Strategy launched in 2012 as a useful reference for stakeholders who see value in a strategic approach to achieving rapid inclusive growth. The analysis was based on publicly available annual data spanning 2008 to 2016 obtained from multiple sources, notably, Enhancing Financial Innovation and Access (EFInA). The progress made on nine key performance indicators (KPIs) of financial inclusion were highlighted nationally and geopolitically. That financial inclusion is achievable in Nigeria was evident from the performance in the South-West geopolitical zone which has already surpassed the 20 percent exclusion rate target. However, the remaining zones, particularly in the Northern part of the country, remain largely financially excluded. Also, while the national financial exclusion rate has reduced from 52.5 percent in 2008 to 41.6 percent in 2016 , more than half $(55.4 \%)$ of the female adult population still remained excluded. Thus, as some similar studies have indicated (Ozughalu \& Ogwumike, 2015, Ajakaiye, 2013, Yunus et al., 2015, Eluhaiwe, 2013), concerted strategy implementation, imbued with agility, would be needed to achieve financial inclusion in Nigeria by 2020 .

Thus, for efficacy of strategy implementation that will move Nigeria faster towards achieving its set targets by 2020, the following recommendations are pertinent:

- Ease of Doing Business at the Grassroots: The business environment should be more informal sector-friendly in terms of robust availability of good roads, reliable and adequate power supply and consistent and clear-headed regulatory policies. As this counters ongoing efforts at financial inclusion in Nigeria, the Federal Internal Revenue Services should stop its current practice of subjecting Microfinance Banks' financial services to Value-Added Tax. Also, given that financial inclusion can only thrive in a peaceful environment where visible enforcement of law and order without fear or favour obtains, government should deal more seriously and proactively with the emerging security concerns surrounding herdsmen-farmers skirmishes across the country.

- Financial Innovation: Financial system operators should leverage continuous research and technology towards expanding the use of tailor-made financial services and products at the grassroots, particularly for women and youths. Development of innovative credit products synergized with information technology, green agriculture and renewable energy is imperative.

- Mobile capacity: Step up use of mobile/electronic technologies so as to drive demand and decrease transactions costs for financial providers and the clients. Operational concerns about the inadequacy of synergy between mobile payment operators and telecommunication companies, cybersecurity, and network connectivity should be addressed. Nigeria should take a cue from Kenya where the financial services sector has been revolutionalized by a paradigm shift from the brick-and-mortar model to the mobile platform, involvement of NonGovernmental Organizations, and other initiatives for sustainable and effective financial inclusion.

- Financial education: Government and other stakeholders should make huge investment in human capital development through qualitative education so as to develop the much-needed financial skills and competencies that are required to imbibe and adapt technology to improve quality of life. In this regard, financial providers should work with learning centres to ensure that financial literacy is available to the poor.

\section{Future Research}

The present contribution is an attempt to move financial inclusion research beyond the traditional macroeconomics of finance-growth and financial intermediation-stability theories to the strategic management realm of inclusive policy implementation for sustainable development. Relying on publicly available data, the present study had revolved around access and usage aspects of financial inclusion, in the belief that financial services should first be accessed before the related issues of quality and impact would 
become paramount. Nevertheless, future research on financial inclusion strategy can be extended to testing some parameters of quality and impact, incorporating interviews and focal group discussions with key stakeholders.

\section{Endnotes}

This is a revised and updated version of the paper titled "Effectiveness of Financial Inclusion Strategy in Nigeria" presented by the author at the $2^{\text {nd }}$ International Conference on Inclusive Economic Growth and Sustainable Development, held at SDM Institute for Management Development, Mysore, India, on November 18-19, 2016.

Funding: This study received no specific financial support.

Competing Interests: The author declares that there are no conflicts of interests regarding the publication of this paper.

\section{Bibliography}

Aduda, J., \& Kalunda, E. (2012). Financial inclusion and financial sector stability with reference to Kenya: A review of literature. Journal of Applied Finance \& Banking, 2(6), 95-120. ISSN: 1792-6580 (print version), 1792-6599 (online).

Africa: The next big economic success story. 2017. Crossref.

Aigbokun, F. (2013). Communicating financial inclusion policy in Nigeria: The role of the media. Bullion Publication of the Central Bank of Nigeria, 36(3)-37(1), 84-87.

Ajakaiye, D. O. (2013). Financial inclusion in Nigeria: Measurements and lessons. Bullion Publication of the Central Bank of Nigeria, 36(3)-37(1), 61-79.

Anderson, A. (2005). The community builder's approach to theory of change: A practical guide to theory and development. New York: Aspen Institute Roundtable on Community Change.

An Introduction to the theory of change. 2016. Crossref.

Central Bank of Nigeria. (2014). Central Bank of Nigeria annual economic report - 2014. Abuja: Central Bank of Nigeria.

Central Bank of Nigeria. (2017). Financial Inclusion Newsletter. Abuja. p. 2-6
Chuku, A. C. (2013). Analysis of external debt dynamics in ECOWAS economies. Economic and Financial Review, Central Bank of Nigeria, 51(2), 93-114.

Constitution of the Federal Republic of Nigeria. 1999.

Coryn, C. L., Noakes, L. A., Westine, C. D., \& Schroter, D. C. (2011). A systematic review of theory-driven evaluation practice from 1990 to 2009. American Journal of Evaluation, 32(2), 199-226. DOI: $10.1177 / 1098214010389321$.

Cull, R., \& Demirguc-Kunt, A. (2012). Financial inclusion and stability: What does research show? CGAP Brief. World Bank Policy Research Working Paper 7255. World Bank, Washington, DC.

Demirguc-Kunt, A., Klapper, L., Singer, D., \& Ouheusden, P. V. (2015) The global findex database 2014: Measuring financial inclusion around the world. World Bank Policy Research Working paper 7255. World Bank Group.

Dutse, U. (2013). Financial literacy and consumer protection in fostering financial inclusion. Bullion Publication of the Central Bank of Nigeria, 36(3)-37(1), 58-60.

Eluhaiwe, P. N. (2013). Financial inclusion initiatives and national economic development. Bullion Publication of the Central Bank of Nigeria, 36(3)-37(1), 52-57.

Enelamah, O. (2017). Nigeria to generate $\$ 88 \mathrm{bn}$ from digital economy - Minister. Retrieved from Crossref

Enhancing Financial Innovation and Access [EFInA]. (2016). EFInA Access to Financial Services in Nigeria Surveys. Crossref.

Enhancing Financial Innovation and Access [EFInA]. (2017). Dissemination of EFInA access to financial services in Nigeria 2016 survey at their financial inclusion conference. The Punch (Nigeria). p. 27.

Evbuomwan, G. O., Okoruwa, V. O., \& Ikpi, A. E. (2013). Effects of deposit money banks' credit on the performance of micro, small and medium enterprises in Nigeria. Economic and Financial Review, Central Bank of Nigeria, 51(2), 63-91.

Fatokun, D. (2013). Viable agent banking and mobile payments system in Nigeria. Bullion Publication of the Central Bank of Nigeria, 36(3)-37(1), 80-83.

Frisby, D. (2014). Bitcoin: The future of money? London: Unbound.

Hindle, T. (2008). Guide to management ideas and gurus. The Economist Newspaper Ltd.

Idowu, B. (2016). Vision achievable: 70\% financial inclusion by 2020. Leadership (Nigeria). p. 37.

Kolawole, O., Osifo, S., \& Abimbola, A. (2017). Impact of monetary policy on financial inclusion. Programme and Book of Abstracts of 3rd Annual International Academic 
Conference on Accounting and Finance, University of Lagos. p. 80.

Kubisch, A. (1997). Voices from the field: learning from the early work of comprehensive community initiatives. Washington, DC: Aspen Institute.

Mangena, A. (2016). Banking at your fingertips. Forbes Africa. p. 46-47.

Manlan, C. (2017). Why Africa should go cashless. Daily Trust (Nigeria). p. 48.

Mercy, C. (2016). Theory of change - Approach and principles. Crossref.

Ministry of Budget \& National Planning. (2017). Federal Republic of Nigeria: Economic Recovery \& Growth Plan 2017-2020. Abuja: Ministry of Budget \& National Planning.

Morebise, Y. (2017). The role of public-private partnership as it relates to financial inclusion and micro-banking. The Nigerian Banker, 27-29.

Musacchio, A., \& Werker, E. (2016). Mapping frontier economies: Where to play and how to win. Harvard Business Review, 40-48.

Oladejo, L. G., Ayatse, F. A., \& Aro-Gordon, S. (2014). Uncovering informal enterprises for financial inclusion: Structural articulation approach as an imperative. Journal of Management and Entrepreneurial Studies University of Agriculture, Makurdi, 1(3)\&4, 60-74. ISSN 2360-8633.

Ozughalu, U. M., \& Ogwumike, F. O. (2015). Inclusive growth and poverty reduction in Nigeria. Bullion Publication of the Central Bank of Nigeria, 39(4), 15-25.

Sachs, J. D. (2015). The age of sustainable development. Columbia University Press.
Sanusi, L. S. (2012). Achieving financial inclusion in Nigeria. Governor, Central Bank of Nigeria's presentation delivered at the Financial Regulators Forum, 18th Economic Summit, Transcorp Hilton. Abuja.

Security and Exchange Commission Nigeria Nigerian Capital Market Masterplan: 10 Year Plan 2015-2025. Abuja: SEC Nigeria. 2014.

Sull, D., Homkes, R., \& Sull, C. (2015). Why strategy execution unravels - and what to do about it. Harvard Business Review, 58-66.

Taplin, C., Clark, H., Collins, E., \& Colby, D. (2013). Technical papers: A series of papers to support development of theories of change based on practice in the field. New York: Actknowledge and Rockefeller Foundation.

Theory of change. 2016. Crossref.

Thomas, D. (2017). Nigeria launches development bank to support SMEs. African Banker, 58-59.

Umoh, P. N. (2016). Banking regulation and supervision: A Nigerian chronicle. Abuja: Pyka Ltd.

United Nations Economic and Social Affairs Department. (2017). World Population Prospects: The 2017 Revision. Crossref.

Yakubu, J., \& Adua, J. (2015). Shadow banking services and its implications for the Nigerian economy. Bullion Publication of the Central Bank of Nigeria, 39(4): 58-71. Yunus, M., Dalsace, F., Menasce, D., \& Faivre-Tavignot, B. (2015). Reaching the world's poorest consumers. Harvard Business Review, 46-53. 